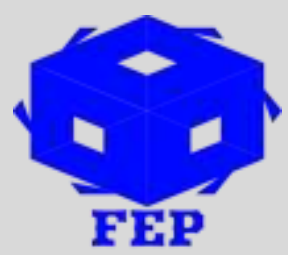

\title{
OUTCOMES OF UNETHICAL PRACTICES BY QUANTITY SURVEYORS IN NIGERIAN CONSTRUCTION INDUSTRY
}

Ebunoluwa Bimbola Akinrata ${ }^{1}$, Deji Rufus Ogunsemi ${ }^{2}$, and Olusola Festus Akinradewo ${ }^{3}$ ${ }^{1,2,3}$ Department of Quantity Surveying, Federal University of Technology Akure,Ondo State, P.M.B 704, Akure, Ondo state, Nigeria

*Corresponding Author: Ebunoluwa Bimbola Akinrata

Corresponding Author Email: akinrataebun@gmail.com

Article Received: 09-05-19 Accepted: 30-05-19

Published: 05-06-19

Licensing Details: Author retains the right of this article. The article is distributed under the terms of the Creative Commons Attribution-NonCommercial 4.0 Licence (http://www.creativecommons.org/licences/by-nc/4.0/) which permits non-commercial use, reproduction and distribution of the work without further permission provided the original work is attributed as specified on the Journal open access page.

\section{ABSTRACT}

Ethics have a verifiable effect on the validity and economic supportability of quantity studying practices and additionally influencing the individual security of the profession. There is a developing consent inside and outside the construction industry that unscrupulous practices are endemic in the construction industry especially quantity surveying practice in Nigeria. This paper thusly, x-rayed the outcomes of unethical practices by Quantity Surveyors in the construction industry in Nigeria, and likewise displays more scholarly and practical approach in dealing with moral appraisal of Quantity Surveyors in the construction industry and ways to improve moral standard among them. Very much organized polls (questionnaire) were self-administered to stakeholders and professionals in construction organizations. Literature review also revealed that unethical practices result to dissatisfied clients, late compensation due to delays, low productivity/efficiency of project team, deterioration in professionalism, poor workmanship, high maintenance, upward review of contract cost, poor project coordination, poor quality infrastructure development, stunted growth of the industry, reduction in the life span of building, loss of public trust, conflicts between client and construction team, poor quality of infrastructural development and loss of public trust. Data were collected and analyzed using Mean Item Score (MIS) and Standard Deviation (SD). The results shows that dissatisfaction of clients, High maintenance cost and Poor workmanship were perceived to be the major ethical misconduct by Quantity Surveyors in the construction industry. The study recommended that Quantity Surveyors should not always make financial benefits, other advantages as their real concern and gain cash unethically by all means. Others professionals in the industry ought to dependably be caution 
and endeavor not to keep any untrustworthy conduct among themselves. Major client in Nigeria construction industry, which is the government need to be fair to the Quantity Surveyors and other professionals in the construction industry.

Keywords: Nigeria, Unethical, Quantity Surveyors (QS), Construction industry, behaviour, Professional.

\section{INTRODUCTION}

Ethics is the branch of philosophy that explores profound quality and the mindsets that guide human conduct (London, 2006). This is regularly portrayed as "doing the right thing" and in the development setting, ethical conduct is estimated by the level of dependability and trustworthiness with which organizations and people lead business. Hornby (2001) characterized ethics as halfway rules that control or impact a man's conduct, and expert ethics as an arrangement of good standards or guidelines of conduct which characterizes occupation moral. Ethics have an undeniable influence on the credibility and economic sustainability of quantity surveying practices as well as affecting the personal security. Robinson et al. (2007) saw ethics as a philosophical investigation of what is correct or wrong in human lead and what tenets or standards ought to administer it. Ethical issues in the building professional and construction industry ought to be viewed as something of intrigue; this will dissipate the feeling that such issues are less critical or separate from the construction industry (Sinha et al., 2004).

Construction is a mind boggling industry in which disputes are normal, vulnerabilities and risks are unavoidable, individual interests of parties are natural, delays are standard, which causes tremendous loss of assets, and aggravations are an everyday occurrence (Arain et al., 2004). Among the construction professionals, Quantity Surveyor is the individual who needs to painstakingly investigate every one of these issues and guarantee that the project complete on time, within the budget, and as indicated by expected quality measures since he/she serve as construction accountant. Professional ethics is presently a prominent subject inside the construction industry (Mason, 2009). Oyewobi et al., (2011) expressed that the Nigerian construction industry has a great degree of vulnerable ethical disintegration because of heterogeneous nature of the industry, which makes it basic for construction experts to show elevated amounts of expert ethics. Unethical behavior is an obstruction to economic improvement and feasible development in any given society. It is more than true to say it is the bane of development in developing nations of the world under which Nigeria is categorized (Ikuabe, 2015).

It is important to highlight that when the lapse in ethical behavior occurs among the construction professionals, the credibility of entire profession is endangered (Pearl, Bowen, Makanjee, Akintoye, \& Evans, 2005). Hence, the construction industry turns out to be all the more ethically touchy, appropriation of ethical standards and the enforcement of standard become matters of increasing importance to society (Abdul-rahman, Hanid, and Yap, 2014). Ethics in Quantity surveying profession is a significant issue and plays a basic part in project achievement, this is on the grounds that ethics is important. Many Quantity Surveyors has position themselves inside the web of interrelationships among different parties in a project environment which involve in this unscrupulous practices. Unethical practices among professionals in the construction industry as however have a considerable measure of 
unfriendly impact on the industry, to the advancement of the economy and human resources. This make Brien (1998) to accentuated that the issue faces any professional community is how might it manage itself successfully to legitimize its self-governance, while guaranteeing that the clients of its individuals and society all in all advantage from the calling's and the individual professional's activities, as opposed to turning into their casualties. It is one of the ethical quality- control issues.

Nawaz and Ikram, (2013) expressed that construction is an exceptionally fundamental part in the advancement of a nation as it is a mother segment behind all exercises identified with improvement of infrastructure; however the most exceedingly awful shades of malice that can wreck ruin in this critical area are corruption, fraud, bid shopping, front end loading, collusion, change order game, payment game, conflicts of interests, cover pricing, claim game, payment game, compensation of tendering costs and negligence. Al-sweity (2013), Professional misconduct has been expanded and there is extraordinary cacophony between genuine conduct of professionals and the ethical obligations which are normal, as the educated party of the industry the desire of them is to enhance the ethical practices and confer their obligations. Thus, this exploration paper intends to assess the outcome of unethical practices by Quantity Surveyors in the construction industry in Nigeria, which introduces an all the more insightful and down to earth way to deal with moral appraisal of Quantity Surveyors in the construction industry in an approach to upgrade moral standard among them.

\section{LITERATURE REVIEW}

Unethical behavior of Quantity surveyors has expedited numerous impacts Nigerian construction industry. One of the aftermaths of these impacts is the raising of the cost of construction to a humiliating level. The pervasiveness of poor pre-contract arranging, inept/ incompetent contractors, inept experts/professional adviser, misrepresentation, poor venture financing/deferred installments, late arrangement of significant professionals, non-application of due process in contract award, hurried readiness/grant/execution of projects, antagonistic market powers/conflicting government strategies, fraud, plan insufficiencies, decision of legally binding course of action/type of contact, and expansion have been distinguished as the causal elements in charge of the high cost of construction in Nigeria (Alutu 2007). As indicated by Hamzah et al.(2010), a poll overview was led in the construction industry in Malaysia, a fast developing economy. Results showed that different types of unethical behaviors have noteworthy effect on construction quality. The study also infers that professional ethics is a pre-requisite to attaining sustained and acceptable quality in construction. Hamzah et al., (2010) specified that quality is subject to ethical conduct in the construction industry, whereby quality and ethics have a typical care introduce, which is to do right things right and it is a demonstrated method to decrease costs improve competitiveness, and create customer satisfaction. It is evident that low ethical guidelines among construction professional have prompted quality issue. The increment in ethical misconduct will see a weighty decrease in the nature of project performance as prove by measurements from the construction related journals. Kadembo (2008), featured that unethical and corrupt practices have a considerable measure of unfavorable impact on the construction industry, including the advancement of the economy and human resources. Unscrupulous or unethical practices has a tendency to misshape construction process and along these lines hamper economic fortune. Unethical performance obstructs the free play of market powers in the industry, 
demoralize financial aid from the outside benefactors /foreign donors and it makes relatively difficult to pull in and global investors disregard the degenerate conditions to the burden of the economies (Kadembo, 2008).

A review of construction industry ethical practices in the USA directed by FMI in conjunction with the Construction Administration Relationship of America (FMI/CMAA, 2004) found that, in $2003,84 \%$ of the responding building owners, architects, A/E firms, construction managers, contractors and subcontractors had encountered, experienced or watched construction industry-related acts or transactions that they would consider unethical. $61 \%$ for each penny of the respondents asserted that unethical behaviour influences public in general impression of the industry; $74 \%$ indicated that it influences the level of trust amongst clients and contractors workers; and 60\% that it unfavorably influences the level of trust amongst contractors and design professionals. As per the report, five most basic unethical issues recognized by the overview respondents were payment games, bid shopping, unreliable contractors, change order games, and claims games. The report noticed that adjustments in business practices on coming about because of mergers and acquisitions, aggressive weights in a low-profit margin industry, outsourcing of resident engineering on government-possessed project and other industry elements frequently prompted unease with respect to where the line between focused business hones and unethical conduct ought to be drawn.

Poll study in South Africa directed by Aigbavboa et al., (2016) demonstrated that unethical practices result to dissatisfied clients, late compensation due to delays, low productivity/efficiency of project team, deterioration in professionalism, poor workmanship, high maintenance, upward review of contract cost, poor project coordination, poor quality infrastructure development, stunted growth of the industry, reduction in the life span of building, loss of public trust, conflicts between client and construction team, poor quality of infrastructural development and loss of public trust. Notwithstanding, low quality issues in the Nigerian construction industry has been distinguished as a noteworthy worry as far back as 1980s (Aibinu and Odeyinka, 2006). As indicated by Aibinu and Odeyinka, (2006), it is a standing principle for the most part that, construction industry must be finished inside particular cost, required time and expected quality, to cut the cost and abbreviate the undertaking time, project quality are constantly disregarded. Deferrals and cost overruns are also consequences of the outcomes of Quantity Surveyors exploitative conduct in construction industry, when a Quantity Surveyor who go about as a contractor purposely exaggerate the time \& cost necessities and misrepresent time sheets keeping in mind the end goal to accomplish a higher cost from the client to cover for the kickbacks (Sohail and Quibble, 2009).

Another result of Quantity Surveyors unethical misconduct in Nigerian construction industry is increased project costs. Prison Business Media Incorporation (2006) watched that deceptive conduct influences the cost of getting project executed in the construction industry and that it adds in the vicinity of $0.005 \%$ and $5 \%$ to the cost. Rodriguez et al., (2005) featured the staggering effect of debasement/corruption in construction as squandered effective costs, tendering uncertainty, increased project costs, economic damage, blackmail, criminal prosecutions, fines, blacklisting, brand damage, and reputational risk among others. These issues of professional ethics has started energetic concern and sober minded dialog among the 
overall population in the construction industry. This was additionally worried by Aigbavboa et al., (2016) and Fan et al., (2001) that one of the result of unethical practices in construction industry has one or the other hindered development of the industry. Due to unethical practices in the construction industry, Shakantu (2006) noted that quality of projects is reduced which affect users' safety and satisfaction. Oyewobi, et al., (2011); Nawaz and Ikram (2013); and Inuwa, Usman and Dantong (2015) also stated that unethical practices lead to poor quality and defective structure development which results in high maintenance cost. Aaronson (2011) placed debasement and others unethical conduct in construction industry influences the cost or time of tasks as well as both the earth for business and policymaking in the construction industry.

\section{METHODOLOGY}

\section{Survey}

The survey examines the conclusions of a sample of Nigerian construction professionals towards the point of the study. To accomplish this point, information assembled by means of a questionnaire covering the outcomes of unethical practices by Quantity Surveyors in the construction industry was observationally tried. Very much organized survey was utilized for the information gathering. The overview included an arbitrary determination of respondents from the available listings of professional consultants and contractors involved in projects in the study area. The professions represented includes Architects, Quantity Surveyors, Civil / Structural engineers, builders and contractors. A rundown of 16 outcomes got from the literature were thusly appraised on a five-point Likert-type scale with focuses 1 and 5 representing strongly disagree and strongly agree, respectively. Other parts of the questionnaire are intended to assemble demographical data about the respondents.

\section{Data collection}

One hundred and thirty two survey bundles were purposively conveyed to the immediate stakeholder in the construction industry. The immediate professionals are the Architects, Quantity Surveyors, Builders and Structural engineers. Both money related and material impetuses can be utilized to enhance survey reaction rate as stated by Boyd, 2002, this was adopted to enhanced respondents response. Altogether, 114 questionnaires were returned out of 132 dispatched, representing 83 percent of general reaction rate which was considered satisfactory. Fellows and Liu 2003 suggested a base reaction rate of 30 per cent from a minimum sample size of 107. The total response got was one hundred and fourteen (114) (83\% reaction rate) this incorporate, Quantity surveyors (32.5\% of respondents), Builders (20.2\% of respondents), Architects (23.7\% of respondents), and Engineers (23.6\% of respondents). Essentially, almost all the respondents (99\%) belong to one or more professional bodies with professional and are duly registered with the irrespective professional bodies. This finding supported Bowen et al. (2008) research which reported $98 \%$ and Vee and Skitmore (2003) that was centered on the Australian construction industry participants in which $90 \%$ of the respondents belong to professional bodies. Ameh and Odusami (2010b) reported that posited $90 \%$ of their respondents are either graduate member, corporate or fellow of their respective professional bodies. The average working experience of respondents was 13.4 years, this suggests that respondents have adequate experience, hence information provided by the respondents pertaining to unethical issues in the construction industry. 


\section{Data Analysis}

Statistical Package for the Social Sciences (SPSS) 16 was utilized in analyzing the data which attempted three separate analyzes. In the first instance, reliability analysis was attempted to decide the consistency of components and dependability of the questionnaire utilizing Cronbach's $\alpha$ model. From the aftereffect of the analysis, the general Cronbach's $\alpha$ reliability for the 16 outcomes was 0.869 , showing a satisfactory interior unwavering quality and consistency of data collection. Furthermore, in light of the fact that the information gathered for the investigation were ordinal in nature. Mean Item Score (MIS) and Standard Deviation (SD) were used to analyze the data and rank the outcomes as indicated on how they influence the construction industry in the study area. Since a Likert of 5-point scale was utilized for the collection of data, the equation for mean item score is composed as:

$$
\text { MIS }=\frac{5 n_{5}+4 n_{4}+3 n_{3}+2 n_{2}+1 n_{1}}{n_{5}+n_{4}+n_{3}+n_{2}+n_{1}}
$$

Where $\mathrm{n}$ is the frequency of each of the rankings.

A cut-off point mean score $>2.50$ on a 5-point Likert-type scale have been declared to be sensible to decide critical or noteworthy variables. Leung (2008) suggested 3.50 cut-off point on a 7-point Likert-type scale (being mid-point). Besides, for a 5-point Likert-type scale, Muhwezi et al., (2014) respected factors with RII < 0.599 (i.e mean score $<2.995$ ) to be unimportant factors. Despite the fact that Opawole and Jagboro (2015) prescribed 3.50 cutoff point on a 5-point likert-type scale, this was thought to be high when contrasted and different entries. This paper embraced $\geq 2.50$ mean score as cut-off point. While Mean Item Score was utilized to rank each item (outcome) while SD was likewise utilized for situations where two items have similar MIS esteem.

$$
\mathrm{SD}=\sqrt{\frac{\sum(x-\mu) 2}{n}}
$$

Where: $\mathrm{SD}=$ standard deviation, $\sum=$ sum of variable, $\mu=$ population mean, $\mathrm{n}=$ number of sample

\section{DISCUSSION OF RESULTS}

Analysis and ranking of outcomes of unethical behavior by Quantity Surveyors in the construction industry. The review of literature regarding this study revealed sixteen (16) possible outcomes of ethical misconduct by Quantity Surveyors on construction industry in the investigation region. The respondents to the questionnaire were required to evaluate the assertion level of the distinguished outcomes of ethical misconduct by Quantity Surveyors on construction industry on a five point Likert scale. The mean analysis of the respondent's recognitions on the result of moral misconduct by Quantity Surveyors presented in Table I. The table demonstrated that the recognized outcomes which are pertinent to ethical misconduct by Quantity Surveyors on construction industry aside from stunted growth of the construction industry and loss of public trust which both have the same mean 3.73; but different Std. Deviation of 0.52 and 0.57 respectively. Both stunted growth of the construction industry and loss of public trust ranked $15^{\text {th }}$ and $16^{\text {th }}$ on table which somehow 
opposed Othman (2012) articulation that "One of these squeezing issues is the unethical behaviour of construction professionals, particularly Quantity Surveyors, which has negative effect on the notoriety of the industry and its professionals and in addition loss of open trust". As appeared on Table 1, dissatisfaction of clients with mean 4.09 and std. deviation 0.78 was ranked first $\left(1^{\text {st }}\right)$. This suggests disappointment of clients is the most striking impact of unethical practice in the construction industry which verified with Nawaz and Ikram (2013); Oyewobi, et al. (2011); and Inuwa, Usman and Dantong (2015) that unethical practices prompt low quality and deficient structure improvement which results to dissatisfaction of clients. High maintenance cost ranked $2^{\text {nd }}$ with mean 4.07 and std. deviation 0.92 which concurred with Rahman, et al, (2007) that unethical behaviour by the construction industry parties impactsly affect the nature of tasks and causes high cost of upkeep. Poor workmanship positioned $3^{\text {rd }}$ with mean 4.07 and std. deviation 0.87 which concurred with Abdul-Rahman et al, (2014) that disappointment with respect to professional personnel to practice the level of care considered sensible the situation being what it is will bring about poor workmanship, insufficient security measures nearby and plan carelessness, and this imply professionals in the construction industry ought to dependably practice obligation of care when leading their duties. The $4^{\text {th }}$ on the ranking is Poor project coordination with mean 4.06 and std. deviation 0.73 .

Table 1

Outcome of ethical misconduct by Quantity Surveyors

\begin{tabular}{lccc}
\hline \multicolumn{1}{c}{ Outcome } & Mean & Std. Deviation & Rank \\
\hline Dissatisfaction of clients & 4.09 & 0.78 & 1 \\
High maintenance cost & 4.07 & 0.92 & 2 \\
Poor workmanship & 4.07 & 0.87 & 3 \\
Poor project coordination & 4.06 & 0.73 & 4 \\
Deterioration in professionalism & 4.01 & 0.96 & 5 \\
Upward review of contract cost & 4.01 & 0.87 & 6 \\
Reduction in the life span of building & 4.00 & 0.78 & 7 \\
Late compensation due to delays & 3.91 & 0.93 & 8 \\
Collapse of buildings & 3.89 & 0.84 & 9 \\
Cost overrun & 3.89 & 0.88 & 10 \\
Low productivity/efficiency of project team & 3.87 & 0.92 & 11 \\
Conflict between client and construction team & 3.84 & 0.52 & 12 \\
Poor quality infrastructure development & 3.82 & 0.90 & 13 \\
Schedule overruns & 3.79 & 0.58 & 14 \\
Stunted growth of the construction industry & 3.73 & 0.52 & 15 \\
Loss of public trust & 3.73 & 0.57 & 16 \\
\hline
\end{tabular}




\section{CONCLUSION}

The discoveries of the research demonstrate that unscrupulous conduct by Quantity Surveyors has an immediate negative effect on the nature of construction in Nigeria. An itemized findings was displayed on the outcomes of unethical behaviour by Quantity Surveyors in their administrations conveyance in this paper. There exit a few zones of worry in the Nigerian construction industry as the low ethical guidelines among Quantity Surveyors has one way or the request influence the nature of work been done. The outcomes displayed in this investigation demonstrated that most clients are not content with the nature of work rendered by most Quantity Surveyors (dissatisfaction of clients). Besides, the untrustworthy practices among Quantity Surveyors has laid crushing consequences for quality administration, nature of works and execution of project in quality measures. Clients are ending up more disappointed because of poor workmanship, disintegration in professionalism, low quality foundation advancement, low profitability/proficiency of project team, poor undertaking coordination and high support cost. In this way, undermining the users and clients of those projects. If this situation continues, the advancement and notoriety of the construction industry will endure. The study recommended that Quantity Surveyors and other construction professionals are expected to carry on with professional trustworthiness and sensible of care.

The study prescribed that Quantity Surveyors should not always make benefits and advantages as their real concern and gain cash unethically by all means. Others professionals in the industry ought to dependably be caution. Major client in Nigeria construction industry, which is the government need to be fair to the Quantity Surveyors and other professionals in the construction industry. Construction professionals in Nigeria should attempt to act with professional honesty and sensible care. If everyone in this sector plays their part well, unethical behaviour will be minimize and eradicated. To the limitation of the study, the procedure utilized in this investigation can be imitated in different areas for additionally thinks about. Moreover, additionally studies may use more strategies in gathering more reliable data on this topic of discussion. For this study, questionnaire was utilized, using several methods will make the results more flexible and precise Method such as interview, comparing data and many more should be adopted. The limitation is inherent in the population of the study.

\section{Reference}

Aaronson S. A. (2011). Limited partnership: Business, government, civil society, and the public in the extractive industries transparency initiative Public Admin. Dev. 31, $50-63$.

Abdul-Rahman, H., Hanid, M. and Yap, X. W. (2014). Does professional ethics affect quality of construction-a case in a developing economy? Total Quality Management \& Business Excellence. 25(3-4), 235-248.

Aibinu, A. A. and Odeyinka, H. A. (2006). Construction delays and their causative factors in Nigeria. Journal of Construction Engineering and Management. 132(7), 667-677. 
Aigbavboa C., Oke A, and Tyali S. (2016) Unethical Practices in the South African Construction Industry. 5th Construction Management Conference Department of Construction Management Nelson Mandela Metropolitan University.

Alutu, O. E. (2007). Unethical practices in Nigerian construction industry: prospective engineers' viewpoint. Journal of Professional Issues in Engineering Education and Practice, 84-88.

Ameh, O. J. and Odusami, K. T. (2010). Professionals 'ambivalence towards ethics in the Nigerian construction industry', Journal of Professional Issue in Engineering Education and Practice, 36(1), 9-16.

Arain, F.M., Assaf, S. and Low, S.P. (2004) Causes of discrepancies between Design and Construction, Architectural Science Review, 47(3), pp. 237-249.

Arain, F.M. (2005b) Strategic management of variation orders for institutional buildings: Leveraging on information technology, Project Management Journal, PMI, 36(4), pp.66-77

Boyd, H.H. (2002), How to Get a Respectable Response Rate, University of WisconsinExtension, Madison, WI, available at: www.uwex.edu/ces/pdande/resources/quicktipsnumerical.html (accessed 23 September 2017).

Brien, A., (1998) Professional Ethics and the Culture of Trust, Journal of Business Studies, Vol. 17, pp 391-409

Fan, L., Ho, C. \& Vincent, NG. (2001) A Study of Quantity Surveyors' Ethical Behaviour in Construction Industry, Construction Management and Economics, 19:19-36.

Fellow, R. and Liu, A. (2008). Research Methods for Construction (3rd ed.). UK: Blackwell Publishing Ltd.

FMI. (2004). The 2004-2005 U.S. Construction Industry Training Report. Retrieved 17 july, 2017, from http://www.fminet.com/global/articles/treport.pdf.

Hamimah A, Norfashiha H, Norazian M, Yusuwan, No. (2012). Ethical Issues in the Construction Industry: Contractor's Perspective. Procedia - Social and Behavioral Sciences 35, 719-727.

Hamzah, A, Wang, C and Yap, X. (2010). 'How Professional Ethics Impact Construction Quality: Perception and Evidence in a Fast Developing Economy, Scientific research and essays, 5 (23), 3742-3749.

Hornby, A. S. (2001). The Advanced Learners Dictionary (6th Edition). Oxford Press, London 
Ikuabe, M. O. (2015). Unethical Practices and Construction Project Cost Performance in Nigeria. In: Ogunsemi, D.R., Awodele, O.A \& Oke, A.E. (Eds). Proceedings of the 2nd Nigerian Institute of Quantity Surveyors Research Conference. Federal University of Technology, Akure

Inuwa, I.I., Usman, N.D. \& Dantong, J.S. (2015) 'The Effects of Unethical Professional Practice on Construction Projects Performance in Nigeria', African Journal of Applied Research, 1(1),72-88.

Kadembo, E. (2008). Corruption and the Distortion of Technology Transfer and Marketing Processes. An Insight into African's Economy Malaise and the Decadence of Its Social Fabric. Journal of Sustainable Development 1(1): 58-68

London, K. 2006. Ethical behavior in the construction procurement process, bringing them home: Research project No: 2002-62-A: A review of ethical decision making literature, report of cooperative research center for construction innovation, Industry and business development, Australia

Mason, J. (2009). Ethics in the construction industry: the prospects for a single professional code, International Journal of Law in the Built Environment, 1(3), 194-204.

Nawaz, T. and Ikram, A. (2013). Unethical Practices in Pakistani Construction Industry European Journal of Business and Management 5(4), 2-4

Opawole A. and Jagboro O. O, (2016). Benchmarking parties; obligation in the execution of concession based PPP project in Nigeria. Journal of place management and development 9(1), 27-46.

Othman Ayman Ahmed Ezzat (2012) An Innovative Protocol For Improving the Ethical Behavior of the Quantity Surveying Profession In South Africa. International Journal of Construction Management. 12(3), 43-62

Oyewobi, L. O., Ganiyu, B. O., Oke, A. A., Ola- Awo, A. W., and Shittu, A. A. (2011). "Determinants of unethical performance in the Nigerian construction industry." Journal of Sustainable Development, 4(4), 175-182.

Pearl, R, Bowen, P, Makanjee, N, Akintoye, A and Evans, K. (2005). Professional ethics in the South African Construction Industry - a pilot study, in front outback conference proceeding, Austrailian universities building educators association, Brisbance, 11-12

Rahman, H. A., Karim, S.B.A., Danuri, M.S.M., Berawi, M.A., Yap, X.W. (2007). Does professional ethic affects construction quality? Quantity Surveying International Conference. Kuala Lumpur, Malaysia.

Robinson, S., Dixon, J.R., Preece, C.N. and Moodley, K. (2007). Engineering, Business and Professional Ethics, Butterworth-Heinemann, Oxford 7(3), 9-15. 
Rodriguez, D., Waite, G., and Wolfe, T., eds. (2005). "The Global Corruption Report 2005.” $\{$ http://www.transparency.org/publications/gcr/download (2005\#download) (march 20, 2016).

Sinha, S, Randolph T, Kulka, J. 2004. Integrating Ethics into Engineering Design Of Construction Process, American Society for Engineering Education Annual Conference \& Exposition.

Sohail M and Cavill S. (2009). Accountability to Prevent Corruption in Construction Projects. Journal of Construction Engineering and Management, 134(9), 729738. 